\title{
連鎖的な再開発事業が成立する中心市街地の「地域文脈」に関する研究 高松丸亀町商店街における地権者・事業主体間の経済システムの分析 \\ A STUDY ON AREA'S CONTEXT OF CITY CENTER IN WHICH SEQUENTIAL REDEVELOPMENT PROJECTS HAVE BEEN IMPLEMENTED
}

Analysis of economic system among proprietors and companies in Takamatsu Marugamemachi Shopping Street

\author{
杉田美和 ${ }^{* 1}$, 飯田大輝 ${ }^{* 2}$, 木多道宏 ${ }^{* 3}$, 辻 寛 ${ }^{* 4}$, \\ 下田元 毅*5，松原茂樹*6，オチェレセスアサレ*7 \\ Miwa SUGITA, Taiki IIDA, Michihiro KITA, Hiroshi TSUII, \\ Motoki SHIMODA, Shigeki MATSUBARA and Seth Asare OKYERE
}

\begin{abstract}
This study aims to comprehend 'structural context' of economic system, by analyzing relationships of investment, funds flow, and decision-making in Takamatsu Marugamemachi shopping street, where redevelopment projects have been implemented in sequence.

1. A common pattern of economic system is formed based on social structure of fund circulation and decision-making in each block among proprietors and organizations, based on concept of subordinate dividend and responsibility for risk.

2. Methodology of urban redevelopment in each block changed depending on economic and local situation, while each economic system is common.

3. Economic system of the block is incorporated into whole district's system..
\end{abstract}

Keywords: Redevelopment project, Area's context, Structural context, Inner city, Economic system 再開発事業, 地域文脈, 組織的文脈, 中心市街地, 経済システム

1.はじめに

\section{1-1. 研究の背景と目的}

地方都市において、人口減少と都市部の衰退がますます進む中、 中心市街地の再生やコンパクトシティ化の手段として都市再開発へ の期待が持たれ、様々な取り組みや実践が行われている。いくつか の事例については問題点も指摘されているが、再開発が今後も都市 再生や都市再編の有力な手法となることから、ここで近年の再開発 事例の効果や問題点を検証し、今後の再開発のあり方に知見を提示 しておく必要がある。

再開発を評価する視点について、(1)施設や開発地区の機能・空間 構成を扱うもの、(2)計画の合意形成や再開発の成立要件などの事業 運営を扱うもの、(3)施設の管理・運営を扱うもの、(4)利用者による 評価を扱うもの、(5)場所性・アイデンティティを扱うもの、(6)周辺 地域一の影響を扱うものがあり、重要な成果が蓄積されている。

例えば(1)については、南部ら 1) が広場・アーケードなど敷地内共 用空地の形態分類と印象評価を行った研究がある注 1)。(2)関して、 古賀ら ${ }^{4)}$ が合意形成のための計画立案支援手法の開発を行っており、 再開発の成立要件については、濱谷ら 5)、服部ら 6) が地方都市にお ける再開発事業の公的支援への依存性を明らかにしている注 2)。
(3)については、河目ら 9) によるオープンスペースの質に関する事 前協議の重要性を指摘した研究がある。(4)につては、北崎ら 10) が 来街者・就業者・居住者へのアンケート調査により、再開発複合施 設の総合評価を高めるための要件を検討したものがあり、(5)に、、 木下ら ${ }^{11)}$ によるアイデンティティの持続可能性を高めるための諸 条件を検討した成果がある。

(6)では、土地利用の変化を捉えた紙野ら 12) の研究があり、大阪府 における再開発 23 事例を対象に、周辺地区における事業実施前後 の変化を検討しており、都築ら 13) は同様に、東京都における再開発 177 事例を取り上げて、周辺地区における容積率や木造住宅率の変 化の動向を分析している。また、沼田ら ${ }^{14)}$ は経済的なインパクトの 観点から、地価の上昇と下落の傾向を詳細に検討し、津島ら $\left.{ }^{15}\right)$ は、 建築系雑誌等において再開発が取り上げられた記事のテーマを分析 し、現代における再開発のイメージや意味の変化を考察している。 本研究は、以上(1)〜 (6)の視点に加えた新たな第 7 の視点として、 再開発事業を周辺地域と一体的に捉え、地域自体の変化や発展を評 価する新たな方法論の提示を試みる。再開発時業が地域においてど のような役割を果たしているのか、地域の社会・空間の中にどのよ うに組み込まれ、さらには地域全体の環境改善や活力の向上を誘導

\footnotetext{
*1 大阪大学社会ソリューションイニシアティブ 特任研究員・経営修士(専門)

*2 (株)大林組 修士 (工学)

*3 大阪大学大学院工学研究科 教授 · 博士 (工学

*4 大阪大学大学院工学研究科 特任助教・都市計画学修士

* 5 大阪大学大学院工学研究科 助教 $\cdot$ 博士 (芸術)

*6 大阪大学大学院工学研究科准教授・博士 (工学)

*7 大阪大学大学院工学研究科 特任助教・博士 (工学)
}

Special Appointed Researcher, Social Solution Initiative, Osaka University, MBA

OBAYASHI CORPORATION, M.Eng.

Prof., Graduate School of Engineering, Osaka University, Dr.Eng.

Assist. Prof., Graduate School of Engineering, Osaka University, MScience in Urban Planning

Assist. Prof., Graduate School of Engineering, Osaka University, Dr.Arts Creative

Assoc. Prof., Graduate School of Engineering, Osaka University, Dr.Eng.

Assist. Prof., Graduate School of Engineering, Osaka University, Dr.Eng. 
するかといった、再開発地区と他地区とを一体的に評価するための 方法論として、「地域文脈」の概念を提示寸る。再開発された街区と 未着手の街区における商業活動が一体的に運営され、成功事例とし て評価されている注3) 高松丸亀町商店街 (香川県高松市) を対象に、 当地区の社会・空間を背後から支える経済システムを「地域文脈」 として捉え、その仕組みを明らかにし、今後の地方都市における再 開発のあり方に知見を得ることを目的とする。

\section{1-2. 地域文脈の定義}

(1)文脈の辞書的意味

まず、「文脈（コンテクスト）」の辞書的な意味を引用すると 16)、 $\mathrm{A}$ ：(文章の）前後関係。文における個々の語または個々の文のあい だの論理的な関係・続き具合、B：(物事の) 背景、状況。ある事柄 の背景、状況。ある事柄の背景や周辺の状況、の二つがある。以下 に、 $\mathrm{A}$ 前後関係と B 背景の意味に対応させて、地域文脈の定義を行 う。

(2)出来事の連鎖の価値としての地域文脈

辞書的意味 $\mathrm{A}$ に相当する意味を取り扱う研究には、千里ニュータ ウンの小学校区を対象にした考察 17$)$ があ、地域における物的環境 や社会的環境の変化を「生活環境とその運営のしくみを向上させる プロセス」ととらえ、地域の人々が積み重ねてきた住環境運営の中 に「継続的に」見出される課題の解決の仕方や、課題解決のための しくみの作り方の連鎖の質を地域文脈と定義している。下田ら ${ }^{18)}$ は宮城県女川町の漁村集落群を対象に、集落群が相互の共同的関係 を形成しながら、漁場・寺社・行事などの空間的・社会的資源を維 持・管理・運用する仕方を分析し、「共生の仕組み」の地域文脈を明 らかにしている。また、田村ら ${ }^{19)}$ は、「地域の文脈」は1.コミュニ ティ、2. まちづくり資源、3. まちづくり課題・目標、4. まちづくり計 画情報、及びその集合で構成されるとし、阪神淡路大震災の被災地 を対象に、震災前のまちづくりと震災後の復興土地区画整理の策定 経過や内容を比較し、震災前後において 4 要素がどのような仕方で 再認識され、再組織化されているかを分析している。また、「地域の 文脈の継承」とは 4 要素が「発展」的に受け継がれていくことであ るとしており、「資源」や「組織」そのものよりむしろ、住民による それらの認識の仕方、考え方の継続性を重視していると考えられる。 以上を踏まえ、A 前後関係の意味に対応する地域文脈とは、地域づ くり・まちづくりに関わる人々が課題解決の仕方を「発展的に」持 続させていく連鎖の質や価值であると定義する。この地域文脈を連 鎖的文脈と呼ぶこととする。

(3)社会・空間組織の形成原理としての地域文脈

辞書的意味 B の「背景」に相当する定義を既往研究に求めると次 のような取り組みがある。例えば、黒野・菊地 $\left.{ }^{20}\right)$ は、水田の維持管 理システムや道の社会的特性を分析することにより散居村の形成原 理を明らかにし、菊池 ${ }^{21}$ は、地域社会の生活行為から農村住居の空 間構成の発展の原理を読み解いている。また、重村 ${ }^{22}$ ) は「意識空間 の構造 (心的空間構造) は、社会的な空間構造とともに物的な空間 構造の背後からこれらを強化し保持している」という考え方を提示 している。黒野・菊池・重村の主張の共通点として、顕在する町並 みや物的環境は、生活様式・社会環境・イメージなど目に見えない レイヤーの㗢きにより成り立っているということである。

また、山口 ${ }^{23)}$ は、建築の間取り、庭、敷地外の関係性から「個と
集合の関係」を解読し、街並みの形成には街区や地区全体の構成原 理である「個と集合の関係」が寄与することを証明している。また、 ムラトーリ学派や陣内らが提唱するティポロジアも同様に、空間組 織や空間どうしのつながりを成立させる空間形成原理を読み取ろう とするものである ${ }^{24)}$ 。これらの研究が扱う空間形成原理の特徽は、 敷地・街区レベルの空間組織には共通の型があり、より大きな地区・ 地域スケールの空間組織の中に組み込まれ生かされている点である。

日本建築学会都市計画委員会創造的地域文脈小委員会は、地域の 社会・空間に形成される組織体の構造を地域文脈と捉え、近年は社 会制度や政策、土地の所有形態、地形・地盤をも文脈として読み解 く研究が現れていること、さらに、組織体の動態や創造的な進化に 関心を持つ研究の重要性に言及している25)。

以上を総括し、本研究におけるB背景の意味としての地域文脈は、 地域や都市における社会組織や空間組織に備わる形成原理であり、 その成立を背後から支える生活様式の在り方、人々のイメージの在 り方をも指すものと定義し、敷地や街区の間に一定の型が見出せる こと、大きなスケールとの間に連結性が見出せること、さらに、一 定の型を継続しながらも、変化（進化）するものと捉える。この地 域文脈を組織的文脈と呼び、前述の連鎖的文脈と区別する。

また、本研究で扱う組織的文脈とは、高松丸亀町商店街 (以下、 丸亀町商店街と略する）における組合や企業組織など社会組織群の 間に形成される意思決定、役割分担、資金の配分や循環など、経済 システムの在り方を指すものとする。

\section{2. 研究対象地区の概要}

(1)再開発計画の経緯

丸亀町商店街は、高松市中心部に位置する 8 町連合商店街の中の 1 つである。江戸時代における高松城城下町の町人町地区にあたり、 親藩大名松平家の下、商業地区として栄えるだけでなく、優れた工 芸品や和菓子を生産し、京都祇園祭にも匹敵する壮麗な都市祭礼「秋 季大祭」が生まれるなど、高度な都市文化が継承される地区であっ た。戦災で街の大半が破壊されたが見事に復興し、フェリー港に近 接寸る地の利も生かし、1980 年代に最盛期を迎えた。しかし、バブ ル期の事業拡大が失敗したこと、そして、1998 年の明石海峡大橋の 開通によるフェリー利用客の減少と、本州から海峡大橋を経由して 四国に至る新たな高速道路網が高松市中心部から離れてしまったこ とから利用客数の激減を招いた。また、商店街のサービスが時代に 対応しきれず、郊外大型店の出現などにより、8 町連合商店街は極 度の衰退を迎えた。

一方、丸亀町商店街は城や港に近く中心市街地の要の位置にあり、 商店街の運営組織である高松丸亀町商店街振興組合（以下、振興組 合と略する）には特別な人材の多さや創意工夫の点で抜きんでてい た上に、東京からのU ターンにより、企画・経営に強い中堅の人材 も加わっていた。振興組合はバブルの最盛期にありながら、将来の 商店街の衰退を予見し、1989 年には青年会が中心となって再開発委 員会を発足させた。当委員会は、全国の再開発の失敗例を調査した 上で、丸亀町商店街再開発計画を立案した。そのコンセプトが今日 に至るまでの再開発事業や商業活動の基本となっている。 (2)再開発の概要

丸亀町商店街再開発計画の大きな特徴は、全長 $479 \mathrm{~m}$ の丸亀町商 


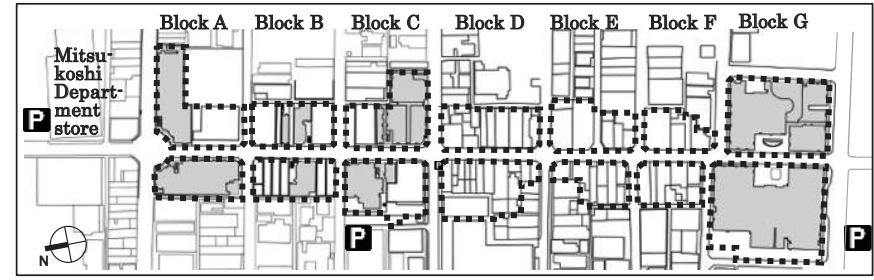

Fig.1 Layout of Blocks in Targeted Area

店街を $\mathrm{A} \sim \mathrm{G}$ の 7 つの街区にゾーニングし、街区ごとに特徴をもた せながら段階的に整備していくことである（図 1)。2006 年にA街 区の再開発ビルが高級店を中心とする「セレクトショップゾーン」 として竣工し、2009 年には B 街区が「フードコート」として整備 され、 $\mathrm{C}$ 街区は「美と健康」の役割で、病院・ビューティクリニッ ク・歯科医院・リハビリセンター・鍼尒院が建設された。A街区と $\mathrm{C}$ 街区のビルの上層階には高齢者向きのマンションが整備され、高 齢社会に対応したコンパクトシティを誘導する開発のモデルとして 注目されている。

これらは、定期借地権制度を活用した民間主導の再開発によるも ので、1998 年に設立された高松丸亀町まちづくり株式会社（以下、 まちづくり株式会社と略する）がテナントリーシングや店舗の配置 構成を一体的に行い、ショッピングモールの魅力を高めている。交 差点のドーム下では一年を通して様々なイベントが開催されており、 「市民持ち込み」のイベントが多いことも特徴である。これらの運 営もまちづくり株式会社によるものである。

$\mathrm{G}$ 街区は「都市生活」と「都市観光」をコンセプトに、店舗・ア ミューズメント・ホテル・大型マンション・駐車場が計画され、2012 年に「丸亀町グリーン」として開業した。現在、D街区で店舗・小 規模オフィス・住宅・福祉施設・駐車場としての計画が進んでいる。

\section{3. 既往研究における位置付け}

\section{3-1. 都市再開発に関する研究}

本論文の冒頭において、再開発に関する既往研究の成果を(1)～(6) に分類した上で、本研究では新たに、再開発事業を周辺地域と一体 的に捉え、地域自体の变化や発展を評価する新たな方法論を提示寸 ることを示した。

本研究と同様の地域的なスケールから再開発を扱ったものに慎ら 26) の研究があり、再開発事業と関連整備事業との相互作用により地 域環境が連鎖的に向上されるプロセスが検討されている。また、沖 村 27) らは、地方小都市における再開発事例を対象に、行政担当者一 のアンケート調查等から、中心市街地再生の可能性を考察している。 再開発事業を周辺地域と一体的に扱う研究の蓄積は未だに少なく、 本研究の新規性は十分にあると考えられる。

\section{3-2. 丸亀町商店街再開発に関する研究}

丸亀町商店街再開発の成功が、どのように成り立っているのかを、 地域文脈（組織的文脈）の読解により明らかにすることが本研究の 目的であり、関連研究としては、同再開発の成功要因を取り上げた 既往文献について整理する。

まず、社会的なシステムに要因を求めた研究があり、木田ら 28) は、 $\mathrm{G}$ 街区再開発敷地内の水神にまつわる祭礼を復活させることに より、商店主、振興組合と地区外の団体との交流が生まれ、再開発
に対する関心が広がることを指摘している。

また、福川 29) は、再開発ビルに中庭、回廊、ブリッジ、階段、裏 路地などの「共」の空間を組み込み、商業床の価值を表通りのみな らず、上階や街区の裏側にも拡大するような空間デザインと、それ を持続させるデザインコードの重要性を指摘している。

丸亀町商店街に関する多くの文献は再開発事業の経営スキームの 特徴を記述しており、福川・西郷 30 は、丸亀町商店街も含めた $2 つ$ の事例を基に「町づくり会社」が再開発を担うことの経営上の意義 ついて検討し、西郷 31)、村岡 32) 、吉田 33 )、定期借地権制度の活用 による「土地の所有権と利用権の分離」や、まちづくり会社が再開 発ビルの商業床を一括管理することによる魅力的なテナントリーシ ングの効果を考察している。また、田中 ${ }^{34)}$ は、地区内に「異例とも 見える多くの目的別法人」が設立され、これらの相関がリスク分散 の効果を指摘していることを指摘している。本論文も目的別会社の 重層的な関係を研究対象とするが、最新の $\mathrm{G}$ 街区再開発事業も含め た地区全体について、契約、資金循環、意思決定の観点から詳細な 調查を行い、丸亀町商店街の賑わいの風景を成り立たせている組織 的文脈を読解する点で、独自の知見を提示するものである。

\section{4. 研究の方法}

\section{4-1. 調査の方法}

2016 年 10 月 26 日、 2017 年 10 月 13 日 11月 18 日の二つの期 間にわたり、振興組合理事長と、A〜Cの各街区における地権者の 共同出資会社である丸亀町商店街壱番街株式会社、同武番街株式会 社、同参番街株式会社（以下、壱番街株式会社等、もしくは各街区 共同出資会社と略する）の社長等注 ${ }^{4}$ )、G街区の丸亀町グリーンを経 営する丸亀町グリーン株式会社(以下、グリーン株式会社と略する) の総務部長にヒアリング調查を行った。

ヒアリング項目としては、(1)丸亀町商店街地区全体における再開 発計画の内容（経緯、開発の進捗、計画理念、各街区の計画内容）、 (2)各目的別企業・組合等組織の体制・事業内容・収支、(3)組織間の 関係 (契約内容、資金の流れ、意思決定)、(4)今後の課題などについ てたずねた。

\section{4-2. 分析の方法}

(1) 再開発事業の基本スキームの整理

定期借地権制度の活用、土地の所有権と利用権の分離、まちづく り株式会社の役割など再開発事業のスキームを理解するための基本 的な情報について、論文・書籍など既往文献、振興組合等の報告書・ 記事 (Web サイト含む)、ヒアリング結果などを集約し整理してお く。なお、G街区については、構想段階での概要が既往文献で紹介 されたことはあるが、実際のスキームが記述されるのは当論文が初 めてとなる。

（2）各組織の関係性に関する分析

振興組合、まちづくり株式会社、街区ごとの共同出資会社など、 様々な組織が重層的な関係を形成しながら、地域や再開発ビルの運 営を行っている。当地区の運営に関わる組織群の関係性について、 (1)契約関係、(2)出資関係、(3)資金の流れ、(4)意思決定の各レイヤー にダイヤグラム化し、その特徵を明らかにする。

(3) 組織的文脈の読み取り

(2)で明らかにした(1)〜 (4)までのレイヤーの特徴を総合し、街区間 


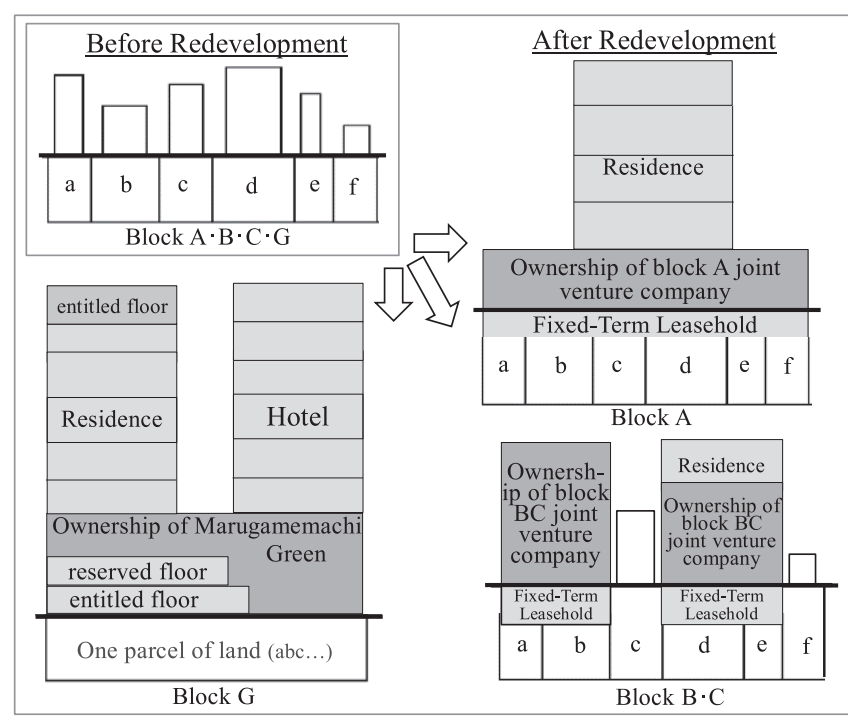

Fig.2 Basic Scheme of Equivalent Exchange

に見出される共通の型、街区レベルと地区レベルにおける接続性な ど、組織的文脈としての特徴を明らかにする。

（4）分析に用いる情報

上記(1)〜(3)の分析に用いた情報のうち、論文、書籍、報告書、記 事等で公表されている内容については、 5 章における当該記述部分 に参考文献の番号を付記する注 5)。また、ヒアリングから得た情報の うち、以上の文献に公表されていない内容については「h」を付記す る。

\section{5. 分析}

\section{5-1. 再開発事業の基本スキームの整理}

$\mathrm{A} \cdot \mathrm{B} \cdot \mathrm{C} \cdot \mathrm{G}$ 街区における再開発事業の基本スキームを以下に整 理する。

(1) A・B・C街区における再開発の概要（図 2 右）

$\mathrm{A}$ 街区の再開発は、高松丸亀町商店街 $\mathrm{A}$ 街区第一種市街地再開発 事業として実施され主 6)、B・C街区は小規模連鎖型再開発事業 (高 松丸亀町商店街 B・C街区) として実施された注7)。

$\mathrm{A} \sim \mathrm{C}$ 街区の地権者は、街区ごとに共同出資会社（壱番街株式会 社等）を作り、この会社と定期借地権契約を締結して利用権を放棄 する。利用権を得た共同出資会社は、再開発ビルを建設し、新たに 設立したまちづくり会社に運営を委託する。地権者の土地は、江戸 時代からの地割を反映し短冊状に区割りされているが、地権者はそ のままの状態で所有を継続できる ${ }^{31,33,37) 。}$

一方、ビルの運営を委託されたまちづくり株式会社は、テナント リーシングや施設運営の高度な専門家を有しており、テナントフロ アーに意欲のある出店者を集め、魅力的な店舗構成とレイアウトを 一元的に運営できる ${ }^{31,32,37)}$ 。元々の地権者が店舗経営に意欲があれ ば新しいビルで出店が可能であり、意欲が無い場合には断念する ${ }^{31)}$ 。 その結果、時代に合った、あるいは時代をリードするような店舗群 が生まれた。元々の地権者は、共同出資会社から地代を得ることか ら、地域に対して関心を持ち続け、まちづくりに間接的・直接的に 参加することもできる ${ }^{31,37)}$ 。以上が再開発完了当初から注目を受け 続けてきた「土地の所有権と利用権の分離」という考えである。
なお、A街区と B・C 街区とで再開発の手法が異なる。

$\mathrm{A}$ 街区の再開発は、110 条全員同意型、第一種市街地再開発事業 による法定再開発として実施された。街区の全地権者の同意を得る ために着手から竣工まで長期間をかけている。 B ・ C 街区の再開発

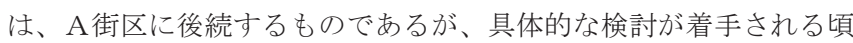
には、エリアの高齢化に対して迅速な対応が必要であったため、街 区内で合意形成ができた部分から再開発を進めていく小規模連鎖型 再開発事業として実施されることとなった ${ }^{29,37)}$ 。最終的に、B街区 東 2 棟、 $\mathrm{B}$ 街区西 1 棟、C 街区東 1 棟、C 街区西 1 棟が共同建て替 えを行い、再開発ビルは 2009 2010 年にかけて完成した。なお、 B ・ C 街区の再開発事業は、都市再開発法を使わない任意の再開発 事業となるため、中心市街地活性化の戦略補助金や都市再生ファン ドが導入された ${ }^{29)}$ 。

$\mathrm{B} ・ \mathrm{C}$ 含めた D・ E・Fの 5 街区では、この小規模連鎖型再開 発の手法を採用することが想定されており、今後生じる任意の小規 模な再開発が、一定のデザインコードやルールを持って、「城下町で ある高松の空間構成を継承しつつ、現代の課題へ応え建物をつくり 直していく」29) ものとなるよう、住民提案型の地区計画が 2008 年 3 月に策定されている。

(2) G 街区の概要（図 2 左下）

$\mathrm{G}$ 街区の再開発は高松丸亀町商店街 $\mathrm{G}$ 街区第一種市街地再開発事 業として実施された注8)。

1995 年に再開発準備組合が設立され、2001 年に都市計画決定と 再開発組合の設立がされた。当初はA 街区で計画が進んでいた都市 計画法 110 条全員同意型によるものと同様の手法を採用することが 検討されたが、規模、地権者の数が A街区よりも膨大であり、合意 形成に困難を極めるとの判断から、都市計画法 111 条地上権非設定 型の手法一と転換されることとなった ${ }^{\mathrm{h}}$ 。

これを推進するため、再開発組合は 2002 年に開発会社森ビル都 市企画(株)とコンサルティングならびに資金協力を依頼したが、森 ビル都市企画(株)にもリスクを負ってもらいたいとの強い意見が組 合側にあったため、再開発エリアの中にあった公共用地を開発会社 森ビル都市企画(株)に購入してもらい、地権者となってもらうこと により解決した h)

権利変換の形式については、再開発後の土地所有を一筆共有型と し、保留床は、ホテル・住宅以外の部分をグリーン株式会社と地権 者が取得している。グリーン株式会社は、地権者の権利床と、グリ ーン株式会社と地権者の保留床を合わせた全ての商業床を一体的に 運営している ${ }^{\mathrm{h})}$ (その仕組みは $5-3$ 章で後述する)。

\section{5-2．再開発前における組織とその関係性}

再開発が着手される前の、組織間の契約関係、出資関係、資金の 流れをまとめて図 3 に示す。なお、以降では図との照合のしやすさ を考慮し、図中に用いている英訳を〈〉内に示す。また、図中の矢 印のうち、本文中の説明に該当する符号を《》內内表記する。

$\mathrm{A} \sim \mathrm{G}$ 街区の寸べての地権者は、賦課金〈Union Levy〉を丸亀町 商店街振興組合に供出し《a 1 》、振興組合はこれを基に商店街でのイ ベントの運営や維持管理を行ってきた。これが丸亀町商店街の運営 のための基本形態である。商店街が衰退することを予見し、駐車場 ビルを建設し、その収益により新たな手を打とうとした。地権者（振 興組合員）より出資〈Investment $\rangle$ を募り《 


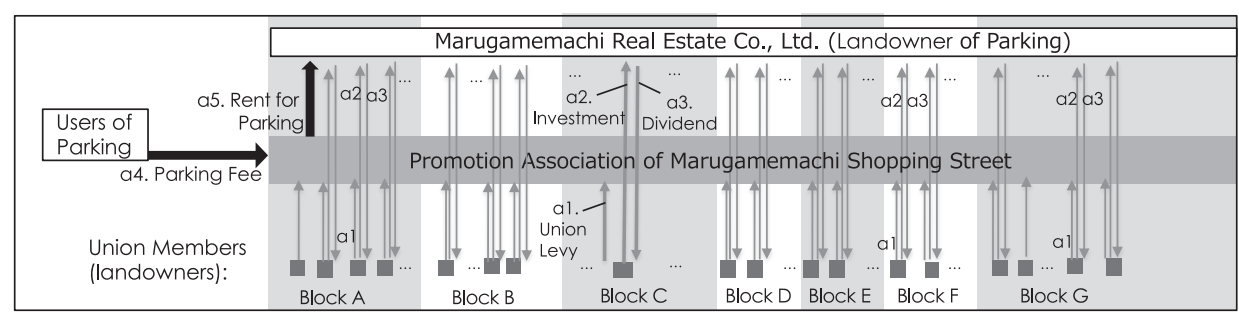

Fig.3 Economic System before Redevelopment Projects

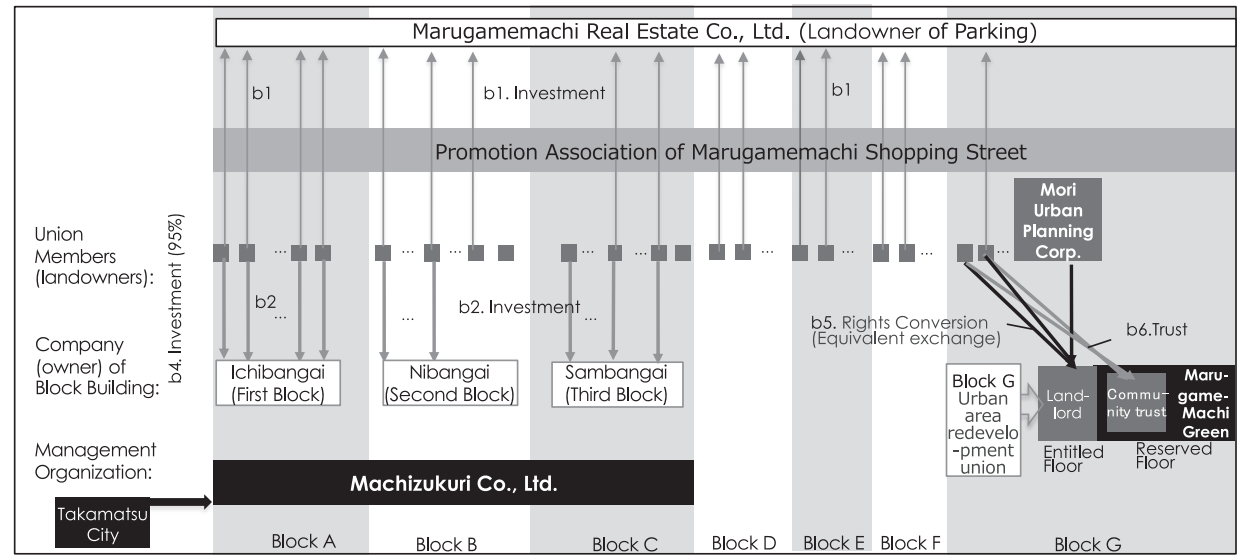

Fig.4 Relationship of Investment

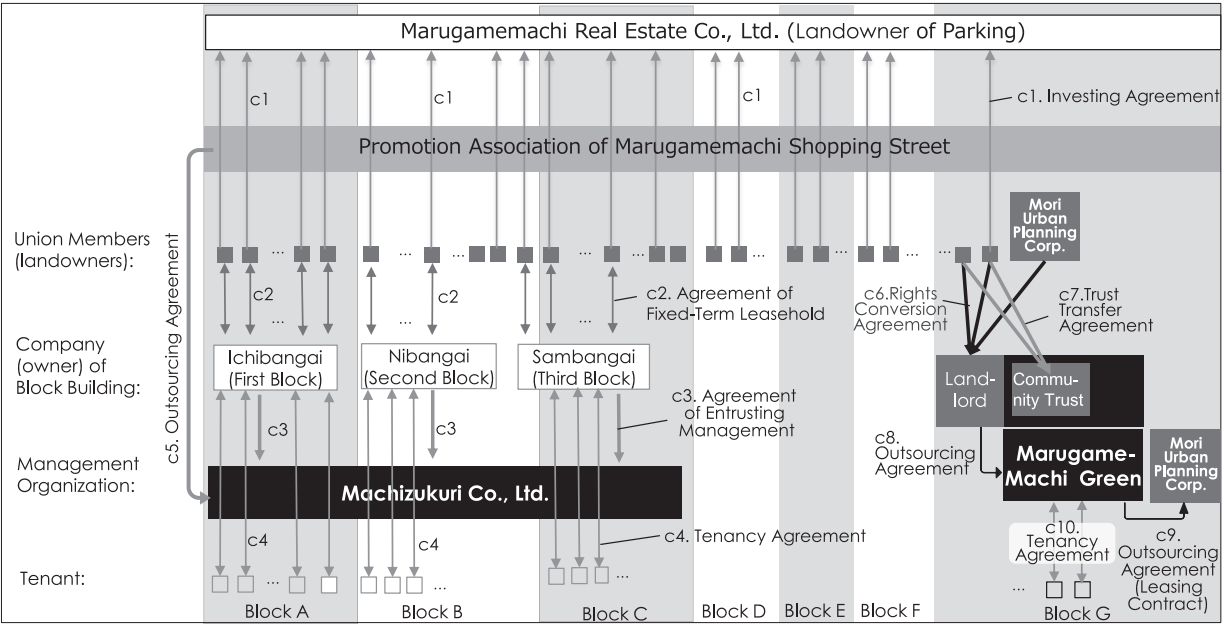

Fig.5 Relationship of Agreement
設立された注9) h) 《b 1 1》。 $\mathrm{A} \sim \mathrm{C}$ 街区の壱 番街・武番街・参番街株式会社は、各街 区の土地の地権者が出資を行なった 《b2 》。まちづくり株式会社は、補助金を 獲得するために第 3 セクターとする必要 があり、高松市と振興組合が出資をして いる《b3, b4 》。通常、第 3 セクターは 51\% 以上の株式が行政に保有されるケース が多いが、意思決定を迅速にするために、 高松市からの出資は要件最低限度の $5 \%$ に抑え、振興組合からの出資を $95 \%$ としている。「リスクを負う人たちだけ で構成する」という理念にも基づいてい る ${ }^{33,37)}$

G街区においては、グリーン株式会社 は、丸亀町グリーンの保留床を買い取る ために、地権者により設立された企業で あり、地権者に支払われる再開発補償費 の 2 割が出資された。森ビル都市企画 （株）も出資に協力した（初期段階のみの 出資のため、図中には記載していない) h)。

グリーン株式会社が再開発ビル「丸亀町 グリーン」の保留床〈Reserved Floor〉 を買い取るとともに、地権者が権利変換 〈Rights Conversion〉により得た権利 床の運営の委託を受け〈b5 》 ささらに地権 者が「増し床契約」(残った保留床の購入) により取得した保留床の運営権の信託 〈Community Trust〉 注 10)を受けること により〈b6》》、ビルの全ての商業床をグリ ーン株式会社が一体的に運営できるよ う土夫をしているh)。その結果、グリー ン株式会社は自社が買った床 (会社勘定 分）と権利者が持っている床（信託勘定 分）の二つの会計を持つ ${ }^{\mathrm{h}}$ 。

会社（以下、不動産株式会社と略する）を設立し、駐車場用地の地 権者とした。これは、商店街振興組合が振興組合法によって税制優 遇を受ける代わりに、土地取得による資産の増加を禁じられている ためである。地権者は不動産株式会社より配当〈Dividend〉を受け る h) $\langle\mathrm{a} 3\rangle$

\section{$5-3$. 組織間の出資関係}

以降、 $5-3 \sim 5-4$ 章では、現在における組織間の関係性を分析 する。地権者と振興組合という元来の構成要素に加え、駐車場経営 を通した自主財源確保のために設立された不動産株式会社、そして、 再開発の推進と再開発ビルの経営のために設立された壱番街・武番 街・参番街株式会社、まちづくり会社、グリーン株式会社など、多 くの会社組織が加えられた。その出資関係について、図4の通り整 理した。

不動産株式会社は、振興組合が地権者から出資を募ることにより

\section{5-4. 組織間の契約関係}

組織間の契約関係を図 5 に示す。壱番街株式会社、武番街株式会 社、参番街株式会社は各街区の再開発ビルの所有者となり、再開発 ビルの管理業務と地権者への地代配当を担う。ただし、各共同出資

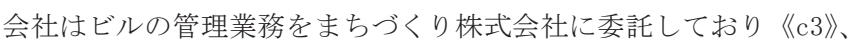
まちづくり株式会社は各共同出資会社の代わりにテナント管理を行 う31 33, 37)。例えば、各店舗には契約時に「売り上げ下限」が設 けられており、下限を下回ったら半年後には退店通告され、直ぐに 店の並びを考慮した順番待ちの店舗が入店するしくみとなっている 《c 4$\rangle$ 。実際に、振興組合の役員関係者であろうとも、このルールに よって店舗を退去させられたことからも、厳格なテナント管理がさ れていることがわかる ${ }^{\mathrm{h}}$ 。

また、まちづくり株式会社は、振興組合の委託も受け、商店街全 体の販促やイベント運営、テナントリーシングなどを行う《 $4 c 5\rangle$ 。特 


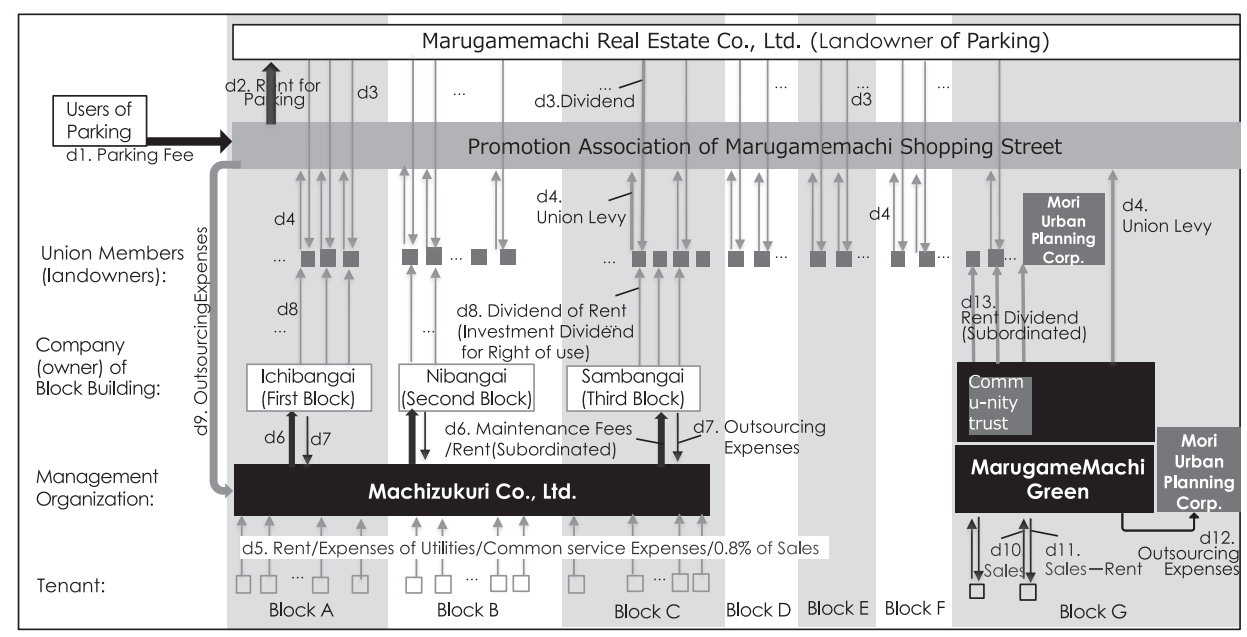

Fig6. Flow of Funds
し、自らの人件費を優先的に確保した後、 各街区共同出資会社に対して（該当ビル のテナントからの徴収分に応じて) 残り の資金を分配する ${ }^{\mathrm{h})}\langle\mathrm{d} 6 \mathrm{~d}$ 。

各街区共同出資会社は、まちづくり株 式会社からの分配のうち、諸経費・積立 金を引いた分を再開発ビル地権者へと （定期借地契約の地代として）配当する 《d 8 》。これは、「配当劣後」 〈subordinated dividend〉という考え 方であり、地権者の収入よりも、まずは 再開発ビルの経営を優先することが担 保されている ${ }^{33)}$ 。

また、この配当の考え方にこそ、A街 区で全員同意を取り付けた重要な工夫
に、テナントリーシングに関しては各街区についてコンセプトを定 め、類似テナントが同じ再開発ビルに入ることによる過当競争を防 いでいる ${ }^{31 \sim 33,35 \sim 37) 。 ~}$

G 街区では、グリーン株式会社が、テナントリーシング、テナン 卜管理、イベント管理など商業活動に直接関与する業務について、 森ビル都市企画(株) と業務委託契約を締結し《c 9 》、グリーン株式会 社内に「運営室」を設け、森ビル都市企画(株)の担当者を（出向し てもらい）常駐させることにより《5-6 章、e11 で後述》、先進的な 商業床経営や有力な事業者誘致などの知見と人脈を得ている ${ }^{\mathrm{h}}$ 。

\section{5-5．組織間における資金の循環}

地権者、振興組合、各会社組織間の関係について、資金のやり取 りからみた関係性を図 6 に整理する。

(1) 商店街全体の資金循環

まず、地権者と振興組合の関係について述べる。 $\mathrm{A} \sim \mathrm{F}$ 街区の地 権者は、再開発の実施の有無にかかわらず、敷地の前面道路に対す る間口幅に応じて $1 \mathrm{~m}$ 当たり 8000 円の賦課金を振興組合に支払っ ている。商店街は左右合わせて $1 \mathrm{~km}$ に及ぶため、月 800 万円、年間 1 億円近い収入がある。G街区も同様の原則により、グリーン株式 会社が地権者としてG街区分の賦課金を一括して支払っている h) $\langle\mathrm{d} 44\rangle$ 。

次に、振興組合と不動産株式会社の関係は以下の通りである。駐 車場の経営は振興組合が行っており、駐車場利用者からの利用料は 振興組合が取得する《 $\langle\mathrm{d} 1\rangle$ 。その利益のうち一定割合が駐車場敷地の 利用料として不動産株式会社一支払われ《d 2 》、そこから出資者に対

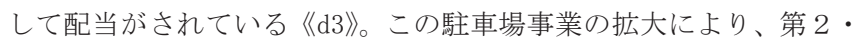
第 3 の駐車場も整備され、近年では年利益約 2 億円となっている h)。 振興組合が再開発も含めた地域環境の向上を推進していく上で重要 な自主財源となっている。

また、振興組合は、まちづくり株式会社に対して、商店街全体の 店舗構成を考慮したテナントリース、商店街全体の販促、イベント 運営などの業務委託費を支払っている《d 9 》。これは、実質的にはま ちづくり株式会社における人件費となっている ${ }^{32,33)}$ 。

(2) 再開発ビルの運営のための資金循環

まちづくり株式会社は、 $\mathrm{A} \sim \mathrm{C}$ 街区再開発ビルに入居するテナン トから、テナント料金、水光熱費、共益費と、売上額の $0.8 \%$ を徵収
がある。多くの地権者はバブル期までに土地代を担保にした銀行か らの借入金により事業の拡大を図ったが、商店街の不振により借金 が担保割れし、返済不能の状況に陷っていた。振興組合は地権者に 対して、借金の返済に再開発の補償費を充当すること、また、地権 者間に生じる充当額の差額については、定期借地の終了期間までに 配当で相殺し、最終的には（再開発事業開始から定期借地終了まで の全期間を通して）全地権者が公平な利益を得ることを提案したこ とが同意の決断を促すこととなったのである ${ }^{\mathrm{h}}$ 。

グリーン株式会社は、丸亀町グリーン入居テナントからテナント 料等を徵収し、運営経費を優先的に確保した上で注 ${ }^{11}$ 、再開発ビル の商業床権利を持つ地権者に対して賃料配当を行う《〈d13》。ここで も、「配当劣後」の考え方を実践しているh)。また、丸亀町グリーン は、森ビル都市企画(株)にテナントリーシング・テナント管理・イ ベント管理の業務委託費を支払い、テナントリーシングに先進的な ノウハウを持つ人材を導入している ${ }^{\mathrm{h})}\langle\mathrm{d} 12 \mathrm{~d}\rangle$

以上の通り、まちづくり株式会社は、振興組合からの依託費を受 けて、商店街全体のビジョンを基に $\mathrm{A} \sim \mathrm{C}$ 街区の再開発ビルに先進 的なテナントリーシングを導入し、また一体的な販促やイベント運 営を行っている。一方、再開発ビルの所有者である各街区共同出資 会社から委託され、日常的なテナントやビルの管理を実施している。 資金の循環の観点から見ても、まちづくり会社は、街区単位の資金 の流れと、商店街全体のスケールの流れの両方に組み込まれている ことがわかる。

各街区の共同出資会社は再開発ビルを所有し、まちづくり株式会 社の管理を通してテナントの賃料を受領している。賃料は「配当劣 後」の原則により決定されるため、再開発ビルの経営状態が安定し なければ、共同出資会社から株主（地権者）に渡る配当は残らない ことになる。株主（地権者）が共同出資会社という街区単位の組織 ごとにリスクを負い、経営に責任を持つという考え方に基づいてい る。G街区ではグリーン株式会社が地権者へ配当するテナント賃料 を「配当劣後」の方式で決定している点で、 $\mathrm{A} \sim \mathrm{C}$ 街区と同様の考 え方が見られる。

\section{5-6．組織間における意思決定の関係}

意思決定の関係を図 7 に整理することで、いかにして地権者を地 域運営に参画する仕組みを構築しているかについて検討する。 


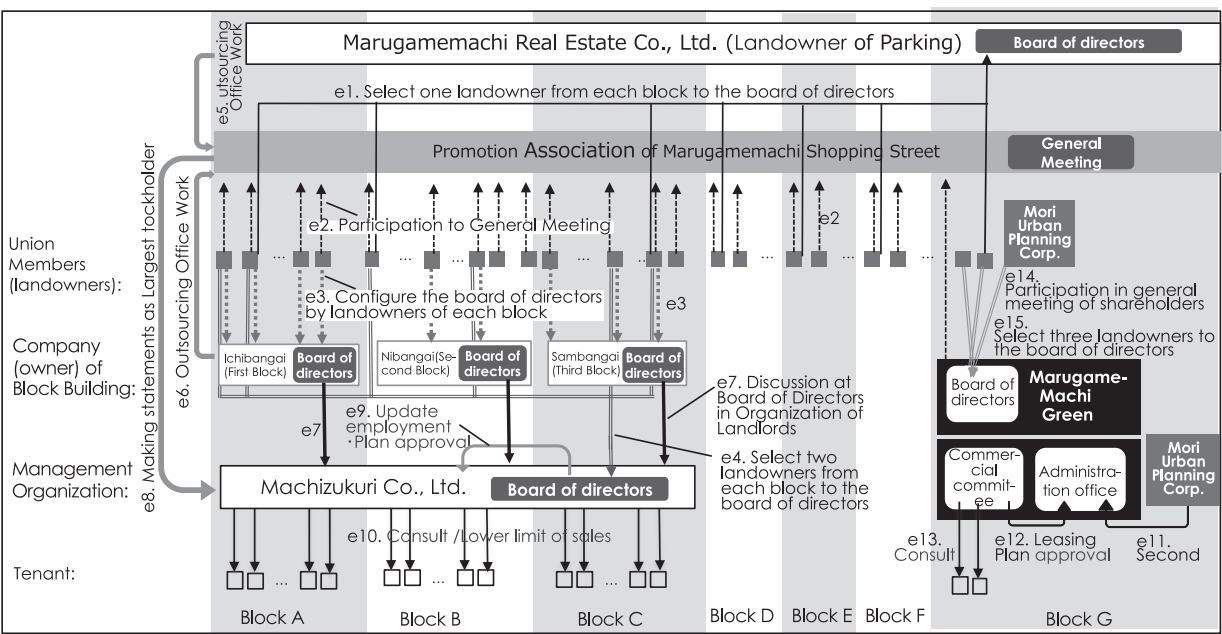

Fig.7 Relationship of decision making

（1）再開発前からの仕組み

初めに、再開発前から存在した振興組合と不動産株式会社の運営 に、地権者の意見がどのように反映されるかを把握しておく。各地 権者は再開発の実施の有無にかかわらず、振興組合の総会へと参加 し、商店街の運営方針へと意見を発信できる ${ }^{\mathrm{h})}\langle\mathrm{e} 2\rangle$ 》また、不動産 株式会社の取締役会〈board of directors〉のメンバーは、各街区 の地権者から 1 名ずつが選抜される ${ }^{\mathrm{h})} 《 \mathrm{e} 1 \mathrm{~V}$ 。このように街区を網羅 するかたちで、地権者の意思決定への参画の機会が確保されている。 (2) 商業戦略に関する意思決定の仕組み

まず、まちづくり株式会社による新たな取り組みへの地権者や振 興組合の意見の反映の仕組みについて分析する。振興組合はまちづ くり株式会社の筆頭株主であり、経営方針について意見する権利を 持つh) 《e8》》。また、まちづくり株式会社の取締役会の構成員には、 各街区から地権者が 2 名ずつ選抜されている h) 《e 4$\rangle$ 。まちづくり株 式会社はテナント運営を担う社員 12 名の会社組織であり、デザイ ナー、テナントリーシング、営業、経理などに秀でた専門家からな るが、取締役会はその成果を年度ごとに評価し、評価に直結した雇 用の更新を行っている。さらに、まちづくり株式会社が行う業務計
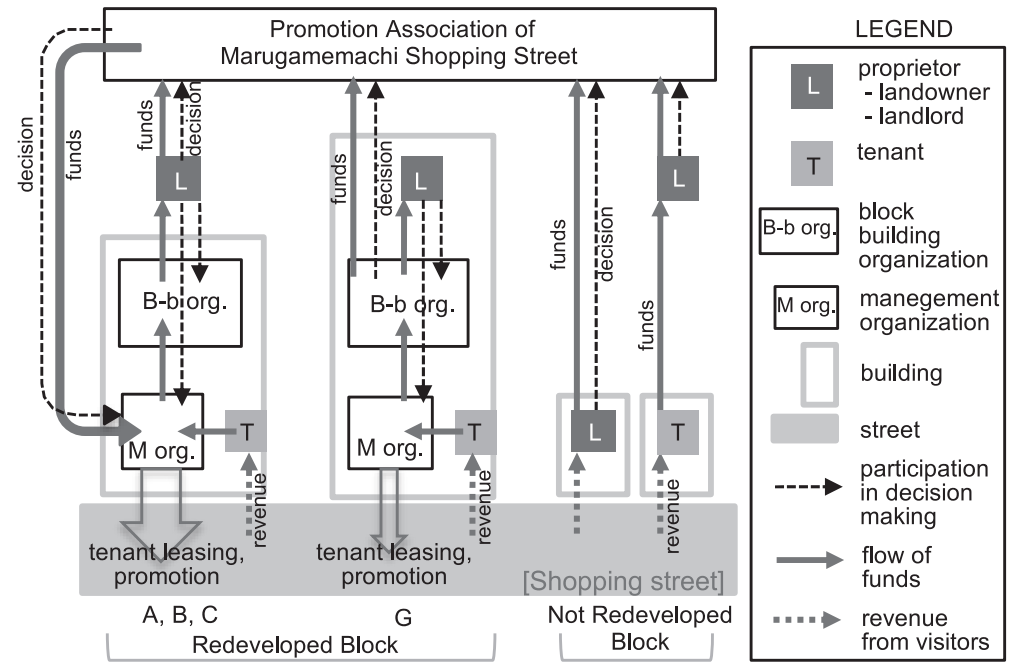

Fig. 8 Pattern of Economic System in each block and Connection to the Large System of the District
画案の承認権も持っている ${ }^{\mathrm{h})}\langle\mathrm{e} 9 \mathrm{\gamma}$

再開発ビルの運営についても、地権者 が各街区の共同出資会社を通して意思 決定に関わる機会が確保されている。各 街区共同出資会社は当該街区の地権者 による取締役会を編成し《e 3$\rangle$ 、月 1 回 の会議において、当該街区を担当するま ちづくり株式会社の社員を招集してお り、地権者がまちづくり株式会社に直接 意見を伝達する機会としている ${ }^{\mathrm{h}}\langle\langle\mathrm{e} 7\rangle$ 。

また、振興組合理事、不動産株式会社 取締役、各街区共同出資会社取締役につ いては兼任可能であり、現在は同一人物 が何役かを兼任し、意思の疎通を確実に しているh)。

G 街区のグリーン株式会社については、地権者（株主）は株主総 会に参加し、経営方針について意見する権利を持っている ${ }^{\mathrm{h}}$ 《e 14$\rangle$ 地権者のうち 3 名が取締役会に選抜される ${ }^{\mathrm{h})}\langle(\mathrm{e} 15\rangle$ 。テナントリー シングについては、会社内に設けられた運営室〈administration office〉が担当し、構成員 5 名のうち 4 名が森ビル都市企画(株) か らの出向であるが《e 11 》、運営室からの提案を承認寸る権限は、社 長と助言者を含む 3 名で構成される「商業委員会」〈commercial committee〉が担い、迅速な意思決定にも配慮している ${ }^{\mathrm{h})}$ 。

G街区は成立経緯からまちづくり会社との直接的な関係が無いが、 新しい商業床経営を導入するというまちづくり株式会社の役割をグ リーン株式会社運営室が担い、地権者に経営への参画の機会を与え る共同出資会社の役割をグリーン株式会社が担い、さらに、商業委 員会が運営室へテナントリース戦略について意見する権利を持つこ とで《e12》、 $\mathrm{A} \sim \mathrm{C}$ 街区と同様の意思決定の構造を形成しているこ とが分かった。

\section{6. 考察とまとめ}

（1）共通の型について

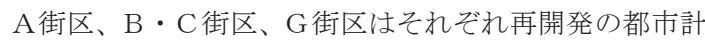
画的な手法が異なっているが、資金の流れと意思決定の関 係からみると、いくつかの共通点があることがわかる。図 8 は、 $\mathrm{A} \sim \mathrm{F}$ 街区の土地所有者〈1andowner〉とG街区の権 利床の所有者〈1 landlord〉をまとめて「権利者」 〈proprietor〉とし、壱番街・武番街・参番街株式会社と グリーン株式会社を「街区ビル組織」〈block building organization〉とし、まちづくり株式会社とグリーン株式 会社運営室を「運営組織」〈management organization〉と した場合の、資金と意思決定の構造をモデル化したもので ある。

$\mathrm{A} \sim \mathrm{C}$ の 3 街区では、「運営組織」がテナントから得た 賃料を、「街区ビル組織」から「地権者」へと地代として 配当し、G街区では、「街区ビル組織」がテナントから得 た賃料が「地権者」に配当される。どちらも健全な経営に 必要な経費を差し引いた上での配当であり、「配当劣後」 という理念が共通している。 
また、 $\mathrm{A} \sim \mathrm{C}$ 街区、G 街区とも、地権者は「街区ビル組織」や「運 営組織」の意思決定に参画できる仕組みとなっているため、地権者 は各街区の再開発ビルの経営に対してリスクを負い、責任を持つこ とになる。さらに、 $\mathrm{A} \sim \mathrm{C}$ 街区と $\mathrm{G}$ 街区は、「運営組織」にテナント リーシング等の専門家を導入し、魅力的な商業床の経営を一元的に 実施している点も共通している。

つまり、地域文脈の観点から言えば、街区を単位とした意思決定 や配当劣後の仕組みこそが、当地域の社会・空間の形成原理であり、

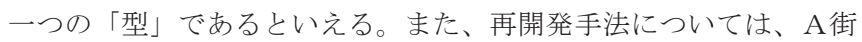
区の全員同意型が「原型」であり、地区特性や経済情勢に合わせて、 小規模連鎖型 $(\mathrm{B} \cdot \mathrm{C}$ 街区) 、地上権非設定型へと変化を遂げている 点も、組織的文脈の持つ特徵であると解釈できる。

（2）大きなスケールの枠組みへの接続

$\mathrm{A} \sim \mathrm{C}$ 街区と $\mathrm{D} \sim \mathrm{F}$ 街区の「地権者」は、間口幅に応じた賦課金 を振興組合に支払い、また G 街区も同様にグリーン株式会社を通し て賦課金を支出している。振興組合はまちづくり株式会社に資金を 支払い、商店街全体の魅力向上のためのテナントリーシング、販促、 イベント運営などを委託している。その成果が利用客を惹きつけ(図 8 の太い点線の矢印)、資金の好循環を生むことになる。振興組合理 事長は、この「BID に準じた」資金の循環こそが丸亀町商店街再開 発の最も重要なコンセプトであると述べている。

意思決定の構造に着目しても、すべての「地権者」は、振興組合 を通して（G街区は街区ビル組織と振興組合を通して）、まちづくり 株式会社の方針の意思決定に寄与寸ることが可能であり、まちづく り株式会社による地区全体の地域経営の方針に組み込まれている。

\section{（3）まとめと課題}

以上のように、都市計画手法、出資関係、契約関係からみれば、 各街区は異なるスキームを持っているが、資金循環と意思決定とい う視点からみれば、共通の型を有しており、それが敷地条件や社会 経済情勢により変化しながらも、全体の仕組みの中に組み込まれて いるという組織的文脈を有していることがわかった。

今後の課題としては、意思決定の構造について、 $\mathrm{A} \sim \mathrm{C}$ 街区の「地 権者」は、「運営組織」への直接的な接続と、振興組合や「街区ビル 組織」を通した間接的なルートの三つを備えているのに対して、他 の街区は振興組合を通した一つのルートしか有していないため、今 後は、「運営組織」ぞうしの水平方向の連携を取っていくことが重要 である。

\section{謝辞}

高松丸亀町商店街振興組合理事長・古川康造様、丸亀町グリーン株 式会社総務部長・萩本豊様はじめ商店街の方々には、多くの貴重な ご助言をいただきました。ここに記して感謝を申し上げます。

\section{参考文献}

1) NAMBU S., ZAINO H.: AMENITY EVALUATION BY SCALE AND PLAN FROM VIEW POINTS OF PLANNERS ON COMMON USE SPACE IN URBAN REDEVELOPMENT AREA, Journal of Architecture, Planning and Environmental Engineering, (Transactions of AIJ), No.456, 199-208, 1994.2 (in Japanese)

2) SHIN J. SATO S.: Design Method and its Consensus-Building through Urban Redevelopment Project in front of The Railway Station Considered Linkage of Surrounding Area - Case Study of Urban Redevelopment Project in front of Machida, Kawaguchi and Kawagoe Railway Station, Journal of the City Planning
Institute of Japan, vol.30, pp. 583-588, 1995 (in Japanese)

3) ITO K., NAKAI N., NUMATA M.: A study on building of a superblock focusing on reduction of public land - Targeting urban redevelopment projects-, Journal of the City Planning Institute of Japan, No.52-3, 1143-1149, 2017.10 (in Japanese)

4) KOGA M., IKARUGA S., OHGAI A., TADAMURA K. KOBAYASHI T.: A STUDY ON A CONSENSUS BUILDING FOR PLANNING IN URBAN REDEVELOPMENT PROJECTS, Journal of Architecture and Planning (Transactions of AIJ), No.660, pp.405-414, 2011.2 (in Japanese)

5) HAMAYA M., OHGAKI N., KUBO K., TSUNEMI M.: STUDY ON TREND OF PUBLIC SUPPORTS IN URBAN REDEVELOPMENT PROJECTS IN HOKKAIDO REGIONAL CITIES, Journal of Architecture Planning (Transactions of AIJ), No.633, 2379-2387, 2008.11 (in Japanese)

6) HATTORI K., ABE H.: A CONSIDERATION ON THE FEASIBILITY STUDIED FROM SUPPORT OF PUBLIC BODIES ON AN URBAN REDEVELOPMENT PROJECT, Journal of Architecture and Planning (Transactions of AIJ), No.687, pp. 1087-1093, 2013.5 (in Japanese)

7) UCHIDA Y., NAKAGAWA Y.: A suggestion for the urban redevelopment project in the central district of local cities -focusing on the vacant rate of reserved floor areas-, Journal of the City Planning Institute of Japan, No.44-1, pp.81-86, 2009.4 (in Japanese)

8) SATO K., NAKAI N., NAKANISHI M.: Attainability of re-redevelopment projects in the first stage redevelopment areas, Journal of the City Planning Institute of Japan, No.42-3, pp. 751-756, 2007.10 (in Japanese)

9) KAWAME H., SAWAKI M., NARUMI K.: A study on Prior Consultation about Open Space Plan and its Use Management in Redevelopment District Plan, The Journal of the City Planning Institute of Japan, No.37, pp.607-612, 2002 (in Japanese)

10 ) KITAZAKI T.: STUDY ON ACTUAL USAGE AND EVALUATION STRUCTURE OF LARGE COMPLEX REDEVELOPED BUILDING -Focusing on 10 facilities in 23 wards in Tokyo, Journal of Architecture and Planning (Transactions of AIJ), No.695, pp. 155-161, 2014.1 (in Japanese)

11) KINOSHITA I., BINDER H.: About Identity and Sustainability in Urban Renewal Projects in Japan, Journal of the City Planning Institute of Japan, 46-3, pp. 463-468, 2011.10 (in Japanese)

12) KAMINO K., KIM H.: A Study on Spreading Effect of Urban Redevelopment Peculiarity in Changes of Urban Activity and Land-use-, Journal of the City Planning Institute of Japan, vol.23, pp.355-360, 1988 (in Japanese)

13) TSUZUKI M., NAKAMURA F., OKAMURA T.: Fundamental study on change of characteristics in urban redevelopment projects and their surrounding areas in Tokyo wards using Geographic Information System, Journal of the City Planning Institute of Japan, No.42-3, pp. 259-264, 2007.10 (in Japanese)

14) NUMATA M., OBASE R.: THE EFFECTS OF REDEVELOPMENT ON LAND PRICE -Case of redevelopment projects in Futakotamagawa-, Journal of Architecture and Planning (Transactions of AIJ), No.665, pp. 1267-1274, 2011.7 (in Japanese)

15) TSUSHIMA H., GOTO H., YOSHIE S.: TRANSITION OF URBAN UPDATE AND SPATIAL CHANGES IN THE 77 PROJECTS OF URBAN REDEVELOPMENT IN TOKYO -Focusing on the aims of the district plan and the articles of architectural journals-, Journal of Architecture and Planning (Transactions of AIJ), No.746, pp. 659-669, 2018.4 (in Japanese)

16) АКІмОтО K.: Introduction to Contextualism of Modern Architecture, SHOKOKUSHA Publishing, pp.22-25, 2002 秋元馨：現代建築のコンテクスチュアリズム入門，彰国社,pp.22-25, 2002

17) Kita M.:STUDY ON FORMATION OF “A PLACE FOR COMMUNITY”FROM THE ASPECT OF AREA'S CONTEXT Comprehending formative process of "Higashimachi Machikado Hiroba"in Senri New Town based on the action of solving issues by the key persons, Journal of Architecture and Planning (Transactions of AIJ),No.675, pp.1023-1031, 2012.5 (in Japanese)

18) SHIMODA M., KITA M, YOSHIZAKI M.: COMPREHENDING MECHANISM OF COMMUNAL LIVES ESTABLISHED BY THE VILLAGES IN ONAGAWA, MIYAGI PREFECTURE, BEFORE GREAT JAPAN EARTHQUAKE Study on rehabilitation of fishing villages with continuation of area's context part 1, Journal of Architecture and Planning (Transactions of AIJ), No.733, pp. 647-656, 2017. 3 (in Japanese)

19) TAMURA H., DOI K.: A Practical Study of the Town Reconstruction Based on the Context of the Pre-Earthquake Community -A Case of the Post-Earthquake 
Land Readjustment Project Area in Morigu, Nishinomiya-, Journal of the City Planning Institute of Japan, vol.34, pp.499-504, 1999 (in Japanese)

20) KURONO H., KIKUCHI S.: THE SPATIAL COMPOSITION OF A DISPERSED VILLAGE FROM RELATIONSHIP BETWEEN THE VILLAGE AND THE CONFIGURATION OF BUILDINGS IN THE PREMISES: A spatial analysis of dwelling system in the Tonami plain Part 2, Journal of Architecture, Planning and Environmental Engineering (Transactions of AIJ), No.507, pp. 151-155, 1998.5 (in Japanese)

21) KIKUCHI S.: Establishment and the society of the "type" of rural residence: Higashiiwai study on the local rural residence Part 1, Journal of Architecture, Planning and Environmental Engineering(Transactions of AIJ), No.413, pp.107117, 1990.7 (in Japanese)

22) SHIGEMURA T.: How the spatial structure of village should be comprehended: Separation of principle for sustainable development and modernism model, "21th century of city and architecture: reflection and prospect", Special researching committee for modern spatial system and Japanese spatial system, Architectural Institute of Japan, pp.11-13, 2008

重村力: 集落の空間 その構造をどう読むか 持続的充実の論理と近代主義 モデルとの乘離，近代の空間システム・日本の空間システム 都市と建築の 21 世紀: 省察と展望, 近代の空間システム・日本の空間システム特別研究委 員会報告書, pp.11-13,2008

23 ) YAMAguCHI H., SHIGEMURA T.: Spatial Structure of Townscape by Detached Building from the Viewpoint of the Relationship between Architectures and Gardens, Proceedings of Housing Research Meeting, Architectural Institute of Japan, pp.113-122, 2009.12

24) JINNAI H.: Logic for Urban Regeneration in Italy, SD Selected Book, Kajima Institute Publishing Co.,Ltd., 1978

陣内秀信：イタリア都市再生の論理, SD 選書, 1978

25) Subcommittee of Creative Area's Context: Finding the field for contribution of area' s contextual design - Reportage and discussion of three challenges, Panel discussion of Committee of urban planning, Annual meeting of AIJ, 2017

創造的地域文脈小委員会: 地域文脈デザインの貢献のフィールドを拓く - 3 つのチャレンジそのルポと討議, 日本建築学会大会都市計画部門パネル ディスカッション, 2017

26 ) SHIN J., SATO S.: A STUDY ON THE MECHANISM OF URBAN IMPROVEMENT ACCORDING TO LINKAGE OF URBAN REDEVELOPMENT PROJECT IN FRONT OF THE RAILWAY STATION AND ITS RELATED PROJECT, Journal of Architecture, Planning and Environmental Engineering(Transactions of AIJ), No.478, pp. 151-160, 1995.12 (in Japanese)

27) OKIMURA Y., MATSUMOTO N., NAKANO T.: A Study on the Retrospective Rating of Downtown Redevelopment by Local City Officials in Charge -In regard to redeveloped local cities with a population of less than 100 thousand-, Journal of the City Planning Institute of Japan, No.44-1, 108-116, 2009.4 (in Japanese)

28) KITA E., GOTO H., SATO H.: A study on the formation of regional community through festival management by Shopping District Promotion Association -In case of Takamatsu-shi Marugamemachi Shopping District, Journal of the City Planning Institute of Japan, vol.46 No.3, pp. 481-486, October, 2011 (in Japanese)

29) FUKUKAWA Y.: Trial for regeneration of inner city -Significance of redevelopment in Marugamemachi, Takamatsu city, Quarterly Machizukuri 23, pp.90-99, 2009.7

福川裕一: 中心市街地再生の試み 高松市丸亀町再開発が意味すること, 季 刊まちづくり 23, pp.90-99, 2009.7

30 ) FUKUKAWA Y., SAIGO M.: A DEVELOPER INITIATED BY INHABITANTS: NEEDS AND CONDITIONS, Journal of Architecture, Planning and Environmental Engineering(Transactions of AIJ), No.467, pp. 153-162, 1995.1 (in Japanese)

31) SAIGO M.: Community-based Development - Trial of Takamatsu Marugamemachi Shopping District for urban regeneration based on the community, Journal of Japan Association for Real Estate Sciences, vol.22, No.1, pp.82-83, 2008.7

西郷真理子: コミュニティベースト・ディベロップメント -コミュニティに 依拠した都市再生: 高松丸亀町商店街の試み -, 日本不動産学会誌, 第 22 巻第 1 号, pp.82-83, 2008.7

32) KOBAYASHI J., MURAOKA S., SAIGO M., et al.: Area management Planning and management by district association, Gakugei Shuppansha, pp.234242,2005
小林重敬，村岡慎也，西郷真理子他：エリアマネジメント 地区組織による 計画と管理運営, 学芸出版社, pp.234-242, 2005

33) YOSHIDA K.: Area management and separation of landownership and right of land-use by means of fixed-term land leasehold -Case study of Takamatsu Marugamemachi shopping street, 'Think about countryside revitalization of tomorrow' edited by The Land Institute of Japan, Toyo Keizai Inc., pp.253-270, 2015

吉田克己: エリアマネジメントと定期借地権による土地所有権と土地利用 権との分離 高松丸亀町商店街の事例を素材として, 土地総合研究所編「明 日の地方創生を考える」, 東洋経済新報社, pp.253-270, 2015

34) SATO S., TANAKA S. et al.: Machizukuri citizen project - Area regeneration by new public commons, Gakugei Shuppansha, pp.256-359, 2011

佐藤滋，田中滋夫他：まちづくり市民事業 新しい公共による地域再生, 学 芸出版社, pp.256-359, 2011

35) FURUKAW K.: Regeneration of Shopping Street -Making a Paradigm Shift from 'Place of Consumption' to 'Place of Life', Monthly PROJECT DESIGN, THE GRADUATE SCHOOL OF PROJECT DESIGN, pp.140-141, 2015.3 古川康造：商店街を再生「消費の場」から「生活の場」への発想転換，月刊 事業構想, 事業構想大学院大学, pp.140-141, 2015.3

36) Kashiwaitchomechiku Machizukuri Promotion Association: Document of the Lecture by Kozo Furukawa, Chief Director of Promotion Association of Takamatsu Marugamemachi Shopping Street, "Regeneration of Takamatsu Marugamemachi Shopping Street"(held on February 8th, 2010),(online), available from $\langle$ http://kashiwa.ne.jp/sys/wp-content/uploads/2013/10/furukawa.pdf $\rangle$ (accessed 2020-3-7)

柏一丁目地区まちづくり協議会：高松市・丸亀町商店街振興組合理事長古 川康造氏講演「高松丸亀町商店街の再生」(2010 年 2 月 8 日開催)記録, (才 ンライン), 入手先〈http://kashiwa.ne.jp/sys/wpcontent/uploads/2013/10/furukawa.pdf〉 (入手 2019-7-7)

37) Promotion Association of Takamatsu Marugamemachi Shopping Street: Strategy for Takamatsu Marugame Machizukuri, available from

〈http://www.japanpa.jp/prize_epa/assets/15thyusyu_keikaku_takamatsu.pdf $\rangle$ (accessed 2019-7-7)

高松丸亀町商店街振興組合: 高松丸亀まちづくり戦略, (オンライン), 入手 先〈http://www.japanpa.jp/prize_epa/assets/15thyusyu_keikaku_takamatsu.pdf〉 (入手 2019-7-7)

注

注 1）他に、街区スケールの空間構成を扱ったものがあり、慎ら 2) は駅前再 開発事業について、敷地内と周辺地区の空間が一体的に連結された「周辺 連結空間」を実現するための計画手法を検討しており、伊藤ら 3）は大街区 化により縮小される公共用地の評価と課題の抽出を行っている。

注 2）再開発の成立要件に関する研究には、内田ら 7）が再開発ビルにおける 保留床や駐車場の割合を検証しもの、佐藤ら 8）が再々開発の実現可能性に 寄与する諸条件を検討したものもある。

注 3）経済産業大臣賞、国土交通大臣賞、総務大臣賞その他多くを受賞し、再 開発事業の模範として内外で高い評価を得、完成後行政関係を中心に多数 の視察者が訪問するようになり、その数は年間 13000 人を超える。 当再開発事業に関連して、がんばる商店 77 選（2006 年度、中小企業庁）、 土地活用モデル大賞・国土交通大臣賞（2007 年、都市未来推進機構）、日 本都市計画学会石川賞（2008 年、日本都市計画学会）、地域づくり総務大 臣表彰（2013 年、総務省）、都市景観大賞・都市空間部門（2013 年度、「都 市景観の日」実行委員会) などを受賞している。

注 4）丸亀町商店街参番街株式会社については社長との面談ができなかった ため、事務を代行している振興組合から情報を提供していただいた。

注 5）分析に用いる情報として、論文・書籍からは参考文献 29, 31～33）を用 い、報告書・記事からは参考文献 35〜37）等を用いた。報告書・記事はWeb サイトに多くが公表されてきたが、その内容は相互に包含・重複している 部分が多く、また、Web サイトから削除されたものもあるため、本論文の参 考文献としては、内容が充実しており、現時点でWeb サイトに公表されて いる参考文献二つ 36,37$)$ に限定した。

また、以上の参考文献の多くはまちづくり株式会社と $\mathrm{A} \sim \mathrm{C}$ 街区、今後介 護施設が充実される予定のD街区の内容が主であり、（再開発の手法が異 なり、まちづくり株式会社との経営的な関係もない）G 街区の記述はほと んど見られない。記述がある場合でも構想段階の内容に触れられている程 度であり、G 街区について具体的な情報を記述する文献としては本論文が 
初めてとなる。

注 6) (1)事業者: 高松丸亀町商店街A街区市街地再開発組合、(2)主用途 : 商業 施設、コミュニティ施設、住宅、駐車場、(3)延床面積 : $16,576 \mathrm{~m}^{2} 、$ (4)施工 区域面積: 0.44ha、(5)総事業費: 約 69 億円、(6)事業期間: 準備組合設立 1994 年 1 月、都市計画決定 2001 年 3 月、組合設立 2002 年 10 月、権利変換計画 認可 2004 年 10 月、工事期間 2005 年 1 月 2006 年 11 月

注 7) (1)事業者：高松丸亀町まちづくり株式会社、(2)主用途 : 商業施設、事務 所、住宅、診療所、(3)延床面積 : 15, $954 \mathrm{~m}^{2} 、$ (4)総事業費 : 約 75 億円、(5)事 業期間 : 着工 2008 年、竕工 2009 年 8 月（B 街区）・ 11 月（C街区東棟）・ 2010 年 3 月 ( $\mathrm{C}$ 街区西棟)

注 8) (1)事業者: 高松丸亀町商店街 $\mathrm{G}$ 街区市街地再開発組合、(2)主用途 : 商業 施設、ホテル、住宅、駐車場、(3)延床面積 : 約 44, $700 \mathrm{~m}^{2}$ 、(4)施工区域面積 : 1. $2 \mathrm{ha}$ 、(5)総事業費 : 約 150 億円、(6)事業期間 : 準備組合設立 1995 年 7 月、 都市計画決定 2001 年 3 月、組合設立 2001 年 11 月、権利変換計画認可 2010 年 1 月、工事期間 2010 年 11 月 2012 年 3 月

注 9）設立当初は、地権者一人当たり 12.5 万〜 150 万円、 70 名から計 4500 万 円の出資を受けた。駐車場は商店街の北側に位置していたため、北側は高 額を負担し、南側は 50 万円以下であった。

注 10）信託契約とすることにより、グリーン株式会社が受けた収益（賃料） には課税されず、地権者に収益が配当された時点で初めて課税されること になり、二重の課税を防ぐことができる。

注 11) テナントは 1 日の売り上げを毎日グリーン株式会社の金庫に預け $[\mathrm{d} 10]$ 、 グリーン株式会社はそこから家賃など諸経費を差し引いた金額を各テナン 卜に戻す $[\mathrm{d} 11]$ 。 


\section{A STUDY ON AREA'S CONTEXT OF CITY CENTER IN WHICH SEQUENTIAL REDEVELOPMENT PROJECTS HAVE BEEN IMPLEMENTED}

Analysis of economic system among proprietors and companies in Takamatsu Marugamemachi Shopping Street

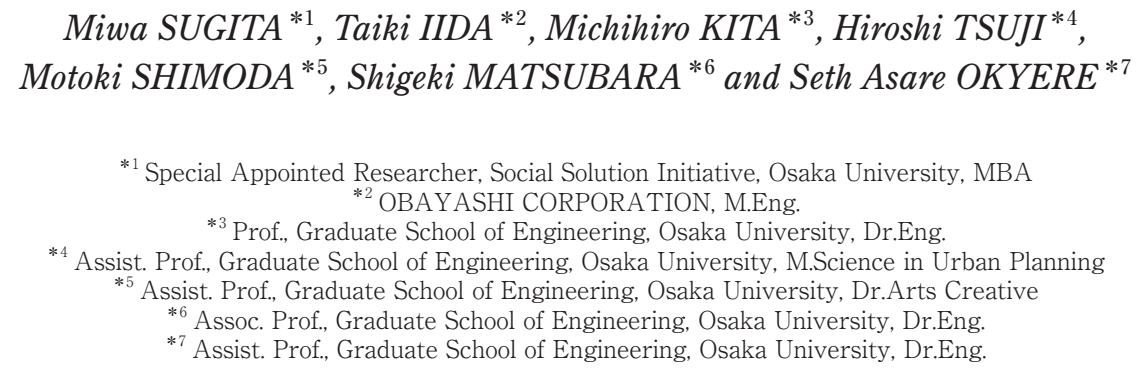

This study targets Takamatsu Marugamemachi shopping street (Takamatsu-shi, Kagawa) where rates it as a best practice, and where commercial activities are integrally operated both redeveloped and undeveloped districts. Then, this study is aimed to consider economic system which supports its society and space from behind as Area's Context (Organizational Context), to clarify its mechanism, and to gain knowledge of a whole concept of redevelopment at regional cities for the future.

There are several social organizations such as business enterprises by purpose and the promotion association of the shopping street at this area. It becomes obvious that there is a common pattern with respect to each district when it is examined their structure of elements such as contractual relationship, capital subscription, funds flow, and decision making procedure. It is to implement advanced tenant leasing method by 'management organization' who is entrusted facility management by 'organization of block building' owning redeveloped facilities. The results showed that rent is distributed to land owners due to subordinated dividend. Besides, the land owners take risk and responsibility for management through participating in decision making of Governing Association. This philosophy is shared with all districts as the common pattern.

Under the certain philosophy, the pattern has characteristics which result in alternation of methods of city planning and redevelopment schemes with area attributes and economic situation. Furthermore, with including in land owners whose properties have been undeveloped, all land owners are integrated into large funds flow in the entire area and mechanism of decision making. Consequently, it is identified that this study field, Takamatsu Marugamecho has characteristics of Organizational Context as defined by this study. Hereafter, it is an issue of horizontal cooperation between governing associations beyond districts. 